\title{
Disabled in rural Victoria: Exploring the intersection of victimisation, disability and rurality on access to justice ${ }^{1}$
}

\author{
Margaret Camilleri \\ Senior Lecturer \\ Criminology and Criminal Justice \\ School of Arts \\ Federation University \\ AUSTRALIA
}

Contact author-Marg Camilleri: m.camilleri@federation.edu.au;+61 353276947

\begin{abstract}
The last decade, in Australia and internationally, has seen an increased focus on and subsequent greater awareness of the inequitable justice system response to accused, offenders and victims with cognitive impairment. In Australia, these inequities have been documented by various national and state based inquiries. It is fair to say, however, that much of the focus and subsequent reform has centred primarily, although not exclusively, on offenders and accused with cognitive impairment rather than victims. This article uses a case study, extracted from a larger study, as a vehicle through which to explore the justice system's response to a young man with cognitive impairment who is a victim of crime, and resides in a rural location in Victoria, Australia. The case study is derived from interviews with the victim/witness and his mother, and provides a sequential overview of the process and outcomes of this case from report to finalisation at court. The paper seeks to highlight the compounding impact of intersectional dimensions of victimisation, disability and rurality on access to justice for victims with cognitive impairment. The case also demonstrates the need to review legislation, procedure, policy and practice to reflect the tangible impact on individuals of so called property or victimless crimes.
\end{abstract}

Key words: victimisation; cognitive impairment; rurality; access to justice; police response 


\section{Disabled in rural Victoria: Exploring the intersection of victimisation, disability and rurality on access to justice - Camilleri}

\section{Introduction}

In Victoria and across Australia, various parliamentary inquiries, government institutions and human rights agencies over the last decade ${ }^{2}$ have articulated concern that the access to justice needs of people with cognitive impairment ${ }^{3}$ (as victims, witnesses and accused) and complex communication needs ${ }^{4}$ are seldom considered. The result of this is an absence of appropriate accommodations and subsequently limited access, or in some instances, no access to the justice system.

This article utilises a single case study situated in the criminal jurisdiction of Victoria, Australia (see Figure 1) which brings into focus the interaction with the justice system of a young adult - who we will call Noah - who has autism. Noah resides with his parents in a rural town of approximately 8,000 residents. In presenting Noah's case, the intersectional dimensions of victimisation, disability and rurality are explored. In so doing, this article provides a chronological description, informed by interviews with Noah and his parent, of each point of contact with justice system processes, key justice representatives and justice agencies. Noah's interaction with the justice system is then analysed and unpacked to consider each intersectional dimension separately. Australian and international literature is used to demonstrate that the justice system response to Noah is not unique, indeed such examples are reflected in the experiences of other people with disability, albeit at varying degrees. To conclude, this article makes recommendations which respond directly to Noah's experience and seeks to heighten awareness and contribute to discourse about access justice systems and processes of people with disability who are victims of crime and who reside in rural areas.

Figure 1: Map of Australia identifying location of the state of Victoria (Image sourced from Google Maps)

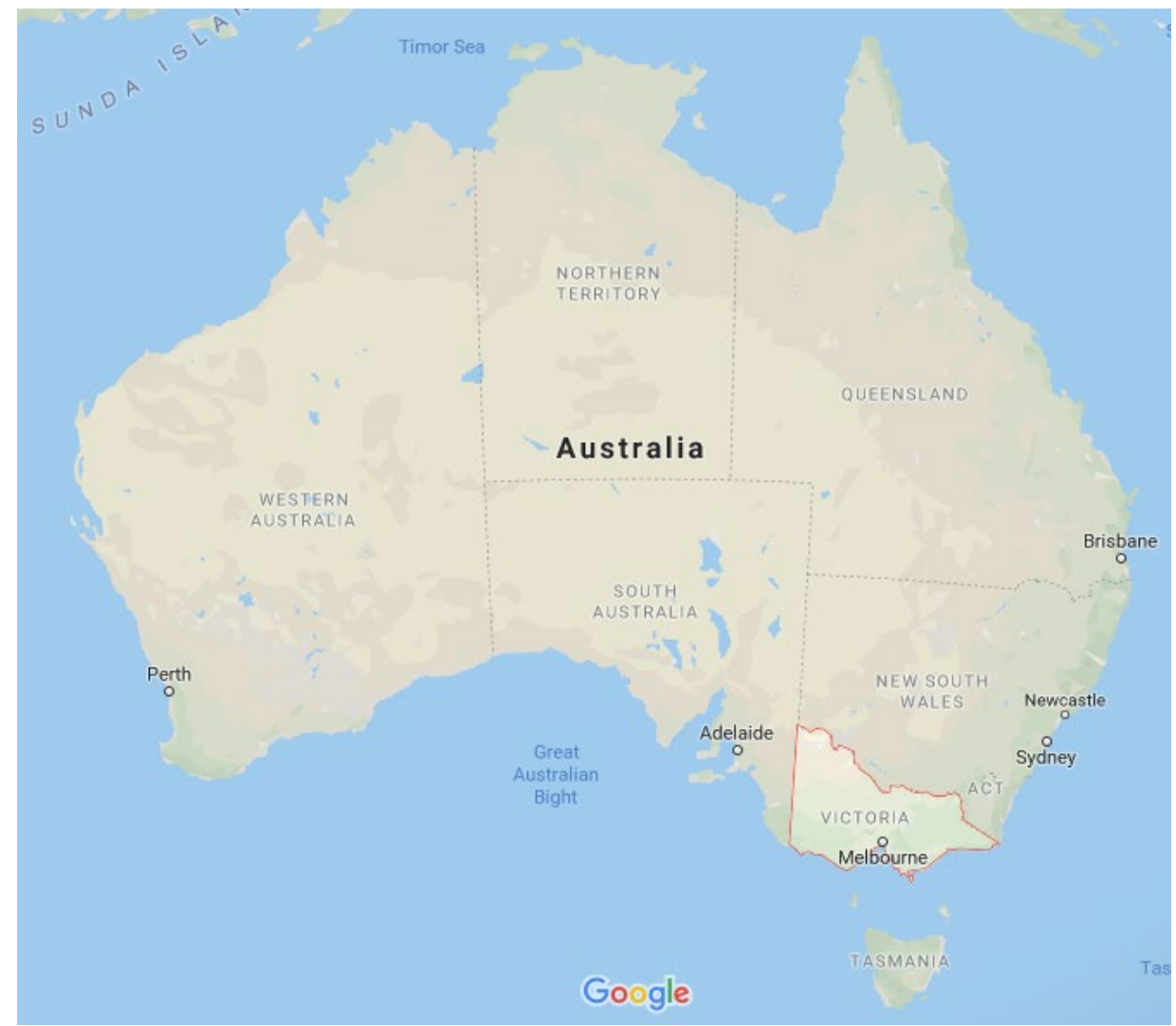




\section{Access to justice - whose perspective?}

Broadly, 'access to justice' refers to both civil and criminal jurisdictions (McQuoidMason, 2013; Pruitt \& Showman, 2014; Rhode \& Cummings, 2017). Simply stated, access to justice is a concept often referred to as "... the ability of people to seek and obtain remedy through formal and informal institutions of justice" (UNPD, 2005 cited in Bedner \& Vel, 2011, p. 5). Discourse in this space highlights the disparities between well-resourced companies, governments or wealthy individuals in contrast to individuals who lack the financial resources to seek representation and redress (Pruitt \& Showman, 2014; Rhode \& Cummings, 2017). In the context of this article, however, the focus is on the criminal jurisdiction.

In the criminal jurisdiction, the phrase 'access to justice' is most commonly used in reference to the accused person's access to legal representation, timely hearings and reducing the complexity of legal proceedings (Martin, 2014). Pruitt and Showman (2014) and Rhode and Cummings (2017) advance the position that the general understanding of 'access to justice' is narrowly defined and limited to access to courts. Further, the narrow focus does not take into account the structural and systemic barriers which are inextricably linked to inequitable access to justice, identifying that the lack of access to legal representation is a symptom of disadvantage. By not addressing the systemic causes of disadvantage, inequitable access to legal representation continues. In her discussion on access to justice for people with a disability, (Ortoleva, 2011) highlights that for people with disabilities, access to justice can be impeded at a range of points in the justice system more broadly. Encompassing the multifaceted limitations of the justice system to the needs of people with disability, Ortoleva (2011, p. 283) suggests that 'access to justice' refers to a "broad concept encompassing people's access to the systems, procedures, information and locations used in the administration of justice".

Shifting the focus from the accused's right to access justice, one might also consider what access to justice looks like from a victim's perspective? In this article, the gaze will purposefully shift to the rights of victims to access justice, thereby considering Noah's 'access to justice' needs and the implications for equitable access to justice when these needs are not met.

\section{Prevalence of and attitudes towards people with disability in Australia and Victoria}

Generally, the collection of data in Australia pertaining to people with disability has improved in the last decade. Notwithstanding the increase in nuanced data, limitations particularly in regards to definitional issues, exclusions of potential participants due to either location or disability type and further disaggregation of data remain.

In Australia, approximately one-quarter (23.9\%) of the total Aboriginal and Torres Strait Islander (ATSI) population $(523,200)$ residing in households have a disability, compared with 17.5 percent of the non-indigenous population (ABS, 2015). The Survey of Disability, Aging and Carers (SDAC) found that people with a disability are more likely overall to have coexisting impairments which affect a person's mobility, self-care, employment and schooling (ABS, 2015). Compared to the general population of Australia, people with disability experience higher levels of unemployment, are less likely to attain 


\section{Disabled in rural Victoria: Exploring the intersection of victimisation, disability and rurality on access to justice - Camilleri}

higher education levels and are more likely to have a fixed income, such as a government pension (ABS, 2015). Further, people with disability are at higher risk to violence (ABS, 2016). For example, adults with disability in Australia are more likely (16\%) to experience sexual violence, physical violence (43\%) and intimate partner violence $(21 \%)$ compared to people without disability respectively sexual violence $(9.6 \%)$, physical violence $(32 \%)$ and intimate partner violence (13\%).

Across the world, the majority of people with disability reside outside urbans areas (World Health Organization \& World Bank, 2011). In Victoria, the majority of the population up to 64 years of age with a reported disability reside in regional $(18.1 \%)$ and rural areas $(19.2 \%)$ compared to 11.1 percent residing in urban areas. Data pertaining to Victoria highlighting the experience of reported discrimination over a 12 month period by people with disability in urban, regional and rural areas depicts greater levels of discrimination experienced by those participants in rural (44\%) compared to inner regional $(18.3 \%)$ and urban (11.2\%) communities (ABS, 2015). Young people aged 15-24 reported the highest incidence $(40.6 \%)$ of discrimination over a 12 month period, followed by those aged 65 years and over (24.8\%) and those aged between 25-34 years (21.8\%) (ABS, 2015).

\section{Human rights of people with disability}

Historically, human rights frameworks have been informed by the medical model of disability. Until recently, disability was described as a condition residing in the individual (United Nations, 2018). The Conventions of the Rights of Persons with Disability draws distinction between impairment (individual) and disability resulting from "the interaction between people with impairments and attitudinal and environmental barriers that hinders their full and effective participation in society on an equal basis with others" (CRPD, 2010, Preamble).

As a signatory to the Convention on the Rights of People with Disability (CRPD), Australia has agreed to "...promote, protect and ensure the full and equal enjoyment of all human rights and fundamental freedoms by all people with disabilities, and to promote respect for their inherent dignity" (CRPD, 2010, Article 1). Section 13 of the CRPD has the most relevance in regards to the rights of victims and witnesses with disability. Section 13 states that:

[State parties] shall ensure effective access to justice for people with disabilities on an equal basis with others, including through the provision of procedural and ageappropriate accommodations, in order to facilitate their effective role as direct and indirect participants, including as witnesses, in all legal proceedings, including at investigative and other preliminary stages.

Notwithstanding that the decade since the CRPD has seen increased awareness of the impediments to access to justice of people with a disability, the barriers impeding access to systems, procedures, and information remain.

\section{Intersectionality of victimisation, disability and rurality}

Central to this article are the multiple dimensions of victimisation, disability and rurality and a consideration of how these dimensions interact and manifest in Noah's attempts to gain access to justice. Each dimension describes the "multiple, intersecting inequalities" 
(Anthias, 2012, p. 3) driven and perpetuated by entrenched systems, informed by one dimensional perspectives of rurality, victims or disability.

Initial theorising on the intersectionality of multifaceted identities highlighted the dimensions of "gender, ethnicity/race and class" (Anthias, 2012, p. 4) as representing points of political oppression and social subordination. The gender, race and class intersectional analysis conducted by Crenshaw (1991) posits the importance of understanding women's experience of battering (family violence) from the perspective of multiple dimensions of subordination, such as race and class, will greatly alter their experience of the same phenomenon. The experiences of and responses to family violence perpetrated against indigenous women would likewise further differentiate the dimension of race, resulting from the historical and contemporary experience of colonisation, which cannot be ignored when responding to indigenous women who experience family violence (Nancarrow, 2006; Olsen \& Lovett, 2016).

Similarly, all people with disability cannot be considered homogenous or sharing the same experience of disability. Indeed, the experience of disability is mediated by multiple dimensions, including impairment: for example, mobility and movement; cognitive function; vision; hearing; and so forth (Meekosha \& Shuttleworth, 2009). Moreover, whether a person was born with a disability or acquired the disability early or later in life, the dimension of disability mediates how a person negotiates the internal "sense of self" and the external constructions of disability (Soldatic \& Johnson, 2017, p. 245). Discrimination, social and/or systemic, as experienced by people with a disability forms part of the external construction of disability.

The experience of disability, including the potential limitations posed by the impairment at an individual level, can be further compounded as a result of the disabling barriers evident in social, cultural and institutional environments. As a conservative institution, the justice system has been slow to respond to the access needs of people with disability. The adversarial nature of the justice system itself presents challenges and obstacles for people with disability. Specific challenges emerge for people with cognitive impairments, such as negative characterisation of disability manifested in challenges to a person's capacity to be a 'good witness'. The 'assessment' of who is a 'good witness' is made at various stages of the justice system process, from first report to investigation and prosecution (Camilleri, 2010). Edwards (2013, p. 312) highlights that there is a convergence of "'adversarial spaces': spaces in which negative legal identities conferred upon disabled people converge with inaccessible environments and procedures".

The constructed representation of rurality suggests homogeneity and a sense of collectivism, along with relaxed lifestyle and an affinity with nature, as experiences of rural life that transcend the divisional boundaries more commonly described as present in the lives of urban counterparts (Donnermeyer, Scott \& Barclay, 2013). However, the experience of rurality as conveyed directly by people with disability, is often absent from the discourse (Soldatic \& Johnson, 2017). Whilst the lives of people with disability residing in rural areas are also subject to perceptions about loneliness and as outcast from the community, such perceptions are not always accurate, however the identities "marked by disability [are nonetheless] complex and multilayered" (Soldatic \& Johnson, 2017, p. 245). In researching gendered crimes in rural settings, scholars have highlighted the significance of rurality and place in understanding the prevalence, severity, reporting of family violence, and the justice and service system response to women who experience family violence (George \& Harris, 


\section{Disabled in rural Victoria: Exploring the intersection of victimisation, disability and rurality on access to justice - Camilleri}

2014; Pruitt, 2008) and intimate partner violence (DeKeseredy, 2019; Hall-Sanchez, 2016; Rennison, DeKeseredy \& Dragiewicz, 2013). While the crime perpetrated against Noah was not gendered in nature, it is argued that the dimensions of disability and how his disability was understood and responded to within a rural context had repercussions that affected the outcome of his case.

To better understand the dimensions and the implications on victims with disability residing in rural areas, it is essential to discuss each system separately in order to appreciate the nuanced implications of the compounding effects of each dimension at the point of intersection.

\section{Understanding disability}

In Australia, the medical model of disability has historically been the dominant paradigm informing how society and its structures understand disability, how we interact with people with disabilities and how people with disabilities see themselves within society. The 'disabled' body and mind is compared to what the medical model considers 'normal', resulting in non-conforming bodies and minds characterised as "abnormal, deviant, inferior and even sub-human" (Loja, Cost, Hughes \& Menezes, 2013, p.191). Using a medical lens, disability is considered a 'problem' residing with the individual, a 'problem' to be fixed, in order to restore the person to normalcy (Thomas, 2004). According to the medical model, it is the impairment, which is disabling and prevents the individual from participating fully in society (Shakespeare, 2013; Thomas, 2004).

As the dominant framework, the medical model is based on ableist assumptions. Such assumptions have informed legislation, policy and practice. Campbell (2001, p. 44) defines ableism as "a network of belief, processes and practices that produces a particular kind of self and body that is projected as the perfect, species-typical and therefore essential and fully human". The consequence for people with disability living within the expectations of an ableist constructed society is one of exclusion, segregation and oppression (Campbell, 2001; Oliver, 1990).

Since the mid-1960s, disability activists and scholars began to challenge the established concept of what it means to be disabled (Edwards, Harold \& Kilcommins, 2015; Goodley, 2001; Oliver, 1990; Rapley, 2004; Shakespeare, 2013). In contrast to the medical or ableist model, the Social Model of Disability provides an alternative lens through which disability is understood. At its core, the Social Model of Disability distinguishes between disability and impairment (Loja et al, 2013; Oliver, 1990; Thomas, 2004) moving from the notion of disability as a 'personal tragedy' (Oliver, 1990) to one which results from systemic structures which ignore the existence of difference (Loja et al, 2013; Oliver, 1990).

The medical model has been a powerful and enduring vehicle through which deficit characterisation of people with cognitive impairment has been imputed and perpetuated. For example, when labels such as intellectual disability are used outside of the medical context, such labels serve to homogenise all victims labelled as such, with respect to capability and capacity (Camilleri, 2010). The 'hierarchy of victims' refers to the level of 'innocence' attributed to an individual victim or group of victims (McEvoy \& McConnachie, 2012). The position on the hierarchy will depend on the context, the type of crime and victim characteristics. For example, McEvoy and McConnachie (2012, p. 232) argue that "in a transnational context... the 'innocent' victim is placed at the apex of a hierarchy of 
victimhood and becomes a symbol around which contested notions of past violence and suffering are constructed and reproduced". Feminist researchers would suggest that female victims of sexual assault occupy a subordinate position on the 'innocence' hierarchy as often their reports to police are seen as false, or the presumption of diminished innocence is fuelled by myths and misconceptions often associated with sexual assault cases (Jordan, 2004).

The contention with respect to victims with disability is that such victims are positioned on a reliability and capacity hierarchy, based on a 'normalcy' bench mark. Typically, this positioning occurs at the first point of contact a victim has with the criminal justice system - the police. At this point, a generalised assumption is made by police about the individual reporting the victimisation experience. The assumption includes perceived characteristics associated with diagnostic labels such as, for example, intellectual disability. The class analysis provided by Garland Thomson (1997, p. 6) describing the "hierarchy of bodily traits which determines the distribution of privilege, status and power" could be similarly applied as the basis for understanding the positioning of victims with disability on the hierarchy of victims. In essence, the presence of cognitive impairment or other impairments which may require alternative forms of communication expose such victims to negative perceptions as less credible or even lacking intelligence (Camilleri \& Pedersen, 2019). The further a victim is perceived as being from 'normal', the further removed such victims are from the 'apex' of the hierarchy, resulting in a reduced likelihood of accessing justice.

\section{[Dis]abling barriers to justice}

The barriers which impede access to justice for people with disability generally, as victims or accused - in particular people with cognitive impairment, and to a lesser extent people with complex communication needs - have been well documented (AHRC, 2014; Australian Law Reform Committee, 2014; Civil Society, 2012; Senate Community Affairs References Committee, 2015; DoJR, 2016; Law Council of Australia, 2018; Parliament of Victoria 2016; PWDA, 2014; Royal Commission into Family Violence, 2016; VEOHRC, 2014; Victorian Ombudsman, 2015; Victorian Law Reform Commission, 2004, 2014). The literature is in agreement that, in Australia, people with disability - and in particular psychosocial, intellectual and complex communication needs - continue to experience significant barriers in accessing justice.

Cumulatively, the findings of these reports and those of other research, present a compelling narrative of the barriers and the consequences of such barriers on the individuals and their families. Barriers to justice for victims of crime in particular, include:

- not being believed (AHRC, 2014; Parliament of Victoria, 2016; VEOHRC, 2014)

- viewed as unreliable and lacking credibility and capacity (AHRC, 2014; Law Council of Australia, 2018; Camilleri, 2008, 2010; Ellem \& Richards, 2018; French, 2007; Goodfellow \& Camilleri, 2003; VEOHRC, 2014)

- a lack of accessible information on how to report, lack of support and accommodations during the justice process (AHRC, 2014; VEOHRC, 2014)

- negative perceptions about the capacity of people with disability to be a competent witnesses (AHRC, 2014; Ellem \& Richards, 2018; French, 2007; VEOHRC, 2014)

- barriers associated with police interviews and cross examination, in particular the framing of questions (Law Council of Australia, 2018), which increases comprehension and hence the opportunity to provide a full and honest response 


\section{Disabled in rural Victoria: Exploring the intersection of victimisation, disability and rurality on access to justice - Camilleri}

These barriers are not unique to the experiences of victims. Indeed, there are numerous studies, including some of the reports named above, which describe in detail the barriers to justice for accused and offenders with cognitive impairment who are disproportionately represented in the justice system, including in prisons (Baldry, Dowse, \& Clarence, 2012; Fogden, Thomas, Daffern \& Ogloff, 2016; McCausland \& Baldry, 2017; McSherry et al, 2017; Shepard, Ogloff, Paradies \& Pfeifer, 2017).

The barriers experienced by victims with cognitive impairment are not unique to the justice system in Victoria, nor indeed Australia. Research conducted in other international jurisdictions identify similar experiences (Edwards, 2013; Edwards et al, 2015; Kilcommins \& Donnelly, 2014; Larson, 2014; Spaan \& Kaal, 2019). Such similarities suggest more than the inadequacy of justice systems in solitary jurisdictions. Rather, they suggest a shared deficit characterisation of people with disabilities and a lack of understanding of the needs of people with such disability, which have been informed by a medical model of disability over centuries.

\section{Impediments to justice in regional and rural locations}

The barriers impeding access to justice are compounded for people with disability residing in rural and regional areas. The phrase 'postcode justice' has been used by Coverdale (2011) to highlight the differential experience and outcomes for people in rural and regional areas compared to their urban counterparts.

Overall, Australian and international research identifies a range of impediments to justice in rural and regional areas. Broadly, these include limited transport and the distance required to access advocacy, legal services and courts (DeKeseredy, 2019; George \& Harris, 2014; Law Council of Australia, 2018; Pruitt \& Showman, 2014; Pruitt et al, 2018 ); and limited internet access and telephone coverage, which can exacerbate the feeling of isolation (Law Council of Australia, 2018; Pruitt et al, 2018). Fewer resources, in terms of justice agencies, support and advocacy services, are also characteristic of rural areas (Coverdale, 2011; George \& Harris, 2014; Pruitt, 2008).

The lack of anonymity associated with living in a rural or regional location can bring mixed experiences in terms of interaction with the justice system. This dimension of rurality has particular significance for women experiencing family violence, affecting the reporting, investigation, support and outcome of hearings, assuming that reports reach the courts. The lack of anonymity means that abusive partners are more likely to be known and have existing relationships in the community including, potentially, with the police, lawyers, prosecutors, judicial officers and other justice representatives (George \& Harris, 2014; Pruitt, 2008). Such existing relationships are often prohibitive to seeking assistance from the community or police (George \& Harris, 2014; Pruitt, 2008). Indeed, the consequences of being recognised when attending court was highlighted by the Royal Commission into Family Violence (2016, p. 139), conducted in Victoria, Australia, which stated that "the risk of encountering people known to them can discourage individuals from bringing an application and attending court".

People residing in rural areas will of course experience many of the same impediments to accessing legal, support and advocacy services as identified above: however, such barriers are compounded for people with disability. While public transport is often limited in rural areas, for someone who requires mobility aids transport options are 
particularly limited. Other impediments related to disability include the lack of information provided in various accessible formats, understanding of augmentative forms of communication and lack of physical access to police stations and courts (VEOHRC, 2014, p. 21); negative perceptions of people with disability by those working within the justice system; and the adversarial nature of the justice system (Courmarelos et al, 2012; Edwards, 2013; Schetzer \& Henderson, 2003). For women with disability experiencing family violence, reporting in the first instance can be impossible when mobility aides or medication is withdrawn by the perpetrator who may also be the carer (Royal Commission into Family Violence, 2016).

\section{The larger study}

The following case study is drawn from a larger study funded by the Victorian Legal Services Board in September 2017. The research sought to document the experiences of the justice system for individuals with 'complex communication needs'. Eleven people who identified as having 'complex communication needs' participated in this project. All individuals had contact with either the civil law or criminal jurisdictions.

Data collection methods used in the larger study consisted of three distinct data sources including interviews (either verbal or using other modes of communication) with individuals with disability or family members, case files (where files were available) and a focus group discussion. Interviews were recorded and transcribed verbatim. Transcripts were analysed using thematic analysis, a process by which the researcher "... looks for recognisable reoccurring topics" (Hawkins, 2018, p. 2). The process of identifying themes within the transcripts includes re-reading the transcript several times to identify and code sections of the text that inform the research questions. Extant data contained all communication relating to the client. The files were provided in electronic PDF format. Any content which identified other individuals was redacted by the advocacy agency prior to researcher access. Files ranged from six to 86 pages in length.

\section{Case Study}

Noah has autism, an impairment which affects how he understands information, and in particular, complex information. The crime of fraud is defined in Victoria's Crimes Act 1958 (s.82) as "[o]btaining financial advantage by deception" (later downgraded), which was perpetrated against Noah. It is categorised in both legislation and policy as an offence against property, not one which is defined as a crime 'against the person'. Despite the lack of recognition of his experience at a system level, the effect of Noah's experience did include fear, anxiety and behavioural changes, typically experienced by victims of crimes against the person. Despite the absence of victimisation recognition at a legislative or policy level, Noah did identify as victim of crime.

Noah's case is not intended to represent the experiences of all people with impairments residing in rural and regional locations. However, it serves to provide further insight into the challenges of accessing justice in such locations, in particular for people with cognitive impairment who are victims of crime.

The case study was informed by interviews with Noah and one of his parents. Noah has been diagnosed as being on the autistic spectrum. He is within the 25-35 year age group and resides with his parents in a rural town, located between 70-100 kilometres from central 


\section{Disabled in rural Victoria: Exploring the intersection of victimisation, disability and rurality on access to justice - Camilleri}

Melbourne. Noah is employed on a part time basis. He drives a car, but only within his local area. He receives support from his parents to understand processes and information. Noah experiences high levels of anxiety in unfamiliar environments. Noah's case took two years from report to police to finalisation at court.

Noah was a victim of crime categorised initially as a property crime - "[o]btaining financial advantage by deception" (Crimes Act 1958, s.82). The perpetrator, who was well known to Noah, used threats and knowledge of Noah's vulnerabilities to manipulate him. The perpetrator used threats to extract several thousand dollars from Noah over a 12 month period. During this time, Noah's parents noticed his behaviour changing; he grew increasingly withdrawn, anxious and was reluctant to venture outside his home or drive his car. Eventually, Noah disclosed to his parents who subsequently reported the allegations at the local police station. As Noah describes, "I went to speak to them [the police] with dad and mum" (interview transcript, Noah).

Once police had to investigate the allegations, a number of challenges presented prior to the matter going before the court. The following section provides a chronological overview of the barriers to justice encountered at each of the stages of progress of Noah's case.

\section{Findings}

\section{Reporting}

The police station in the local town where Noah lives is categorised as a non-24 hour station, meaning that its capacity to respond is limited. The station is staffed by two police officers including a sergeant, one of which is part time and supported by one unsworn staff member. The initial police response was that a report could not be taken. In describing the experience of reporting the allegations to police, Noah's parent reflected upon the response to informing police that Noah is autistic: "We explained his condition [he is autistic] and [the police] basically said, oh, you wouldn't get anywhere with it" (interview transcript, parent). Not accepting this response, the family advocated at a senior level within Victoria Police, questioning why the matter would not be investigated. Advocacy by Noah's parents resulted in the matter being investigated.

\section{Police interview}

In all, there were two interviews conducted by the police with Noah. Initially, an interview was attempted at the local police station. As Noah recalls, "[w]e did try a voice recording interview and they said maybe it's better off being a video interview. That's [be]cause I was a little nervous to start from the beginning, because it started with a mistake I made and I was panicky about it" (interview transcript, Noah). The interviews seemed to identify what was an apparent lack of experience on behalf of the police in conducting interviews with victims with cognitive impairment. As the following comment from Noah's parent suggests (interview transcript, parent), the questions needed to be reframed for Noah to be able to understand and respond:

...we [Noah's parents] didn't say anything and we weren't asked to say anything. But, there was a couple of occasions I interrupted and I put it in another way, 'cause he said, I don't understand. I said, well, [Noah], what she's trying to ask you is such and such. And I would say, I would put it this way. 
When the audio interview at the local police station was deemed unsuccessful, the police officer advised Noah's parents that another interview would be scheduled with the police at a larger regional town, located approximately 50 to 80 kilometres (31 to 50 miles) away. Noah was anxious about attending this interview; however, a support person was not permitted to accompany him during the interview. As Noah was a victim of crime rather than an accused person, he was not eligible for assistance by an Independent Third Person (ITP). The Office of the Public Advocate recruits and trains volunteers who can attend police interviews to assist accused persons with a cognitive impairment. The role of an ITP is to ensure the accused understands why they are being interviewed, is aware of their rights and to assist in the communication between police and the accused, ensuring that the accused understands the questions (Office of the Public Advocate, nd).

During both interviews, the questions were not framed in a way that took Noah's communication needs into account. His parents, who would ordinarily support Noah's comprehension of information, were not allowed to be present during the interview for fear their presence would jeopardise the interview. In the following extract, Noah's parent indicates that they were left feeling uncertain about whether his response to questions was sufficient:

Of course, we were ushered out and [Noah] was left with that interview by himself, to go through that interview process. He was very unsure about a lot of his answers when he came out of that interview.

Unsurprisingly, the police were dissatisfied with the quality of the interview, indicating that the "interview did not go well and they were not convinced that a conviction was possible" (interview transcript, parent).

\section{Delays in hearing the matter at court}

There were a number of circumstances which resulted in multiple delays before this case would eventually reach court, approximately two years after the first report was made. The first delay was the result of police reluctance to take the initial report. Another major delay was due to the file being lost. As Noah's parent recalls, "the brief was lost and that caused the case to be put back another year" (interview transcript, parent).

The consequences of the lengthy delay until the case was heard in court was significant for Noah and indeed his parents, doing their best to reassure him (interview transcript, parent):

[Noah] was full of anxiety and unfortunately, when [Noah] becomes anxious he becomes a little bit paranoid with it all. And it becomes a daily, sort of, I don't know what I'm gonna do, I don't know what I'm gonna say, you know, I'm so worried about this.

Other delays were as a result of police unavailability due to either performing other duties away from the police station or the police officer working part time. This extract from Noah's parent, concerned the availability of police officers at a rural police station: 


\section{Disabled in rural Victoria: Exploring the intersection of victimisation, disability and rurality on access to justice - Camilleri}

It's [a rural police station] supposed to be open, but unfortunately they come and go so quickly. And half the time you go there and it's ... during the day ... and it's not open. They do not have enough police.

As is the case for other victims of crime, being kept up to date about the progress of the investigation was important for Noah and his family (interview transcript, parent):

I wasn't getting much feedback from police [station], from [police officer]. And [police officer] wasn't full-time, so it was very hard to get hold of [police officer] sometimes, to find out what was happening.

The lack of continuity of staff at some police stations is often unavoidable, however it does create delays while the recent incumbent becomes familiar with the investigation (interview transcript, parent):

And also, the sergeants were changing all the time. So, I mean every time...every time we couldn't get a hold of the sergeant. Sometimes [Noah's parent] would actually ring and say, I want to talk to your sergeant. No one was getting back to us, about these questions...we'd got all these questions about what's gonna happen, and when it's gonna happen and such and such. And [police officer] would get on the phone and would sort of be a little bit upset, because obviously he's [senior sergeant] said, you know, you haven't got back to these people, they wanna know what's going on... where the case is going. 'Cause it took months. They had the case for ...they were doing their investigation for some... many months, basically.

\section{The decision to downgrade charges}

Noah's parents were originally told that the type of crime was considered to be at a level of seriousness that the matter could be heard in the County Court (interview transcript, parent). However, the decision had been made by the police and prosecutor to downgrade the charges so that the matter could be heard in the magistrates' court. It appeared to Noah's parent that the police and prosecutor had "already made up their mind that it would be better for [Noah] to go for the lesser charge [because he is autistic] (interview transcript, parent). Neither Noah nor his parents were involved in this decision.

The following extracts from the interview with Noah's parent suggest that the police and prosecutor were concerned that Noah was anxious about giving evidence, and that this may compromise the potential for a successful prosecution:

They did say he would have to go into the box, he would have to give evidence. He would have to do such and such, whereas if it was a lesser charge, then he might not have to do this. And they're more likely to convict him on the lesser charge, than what they are on the other charge.

They [police] said that it would be very difficult to prove with [Noah], 'cause he wouldn't be able to take the stand successfully.

\section{Support during and after the hearing}


Until the day of hearing, Noah and his parents had not met the prosecutor. Noah was very anxious and becoming increasingly so, as the date of the hearing drew closer (interview transcript, parent):

... look we're all going to be there, we're gonna be there for you. Everything's gonna be alright. No-one's going to put you in a bad position. This would go on, you know, for months basically. It went on for months and it got worse as the day [court hearing drew closer].

The accused was initially not represented; as such, he would be the person crossexamining Noah during the hearing. Cross-examination of the victim by the accused would not be acceptable in instances where power is believed to be exerted by the accused against the victim. As the crime in this instance was not considered to be a 'crime against the person', Noah was not recognised as a victim.

Noah was already anxious about going to court. His biggest fear was that "I was scared of... I was more scared of seeing [defendant] eye to eye with [defendant] again. I avoided eye contact with him. I just, I just I turned my head as he walked past me. I didn't want him to look at me" (interview transcript, Noah). Noah's family were also concerned that Noah would be cross-examined by the perpetrator.

The prosecutor had not intended to lodge an application with the court requesting that the victim be considered a vulnerable witness, thus enabling access to various provisions available to such witnesses. An application was lodged with the court a short time prior to the hearing, after a member of Noah's extended family had suggested this as an option. Vulnerable witness provisions are available primarily to victims of family violence and sexual assault, in recognition that these crimes are steeped in a power relationship used by the perpetrator over the victim. Applications can be made to the court for such provision to be made available, subject to the victim being considered to be a vulnerable witness. The provisions include the use of screens in the court room to ensure there is no line of vision between the defendant and the victim while they give evidence; the use of remote witness facilities to give evidence by closed circuit television; and finally the option to have a support person sit with the witness while they give evidence (Magistrates' Court Act 1989: s.4K).

\section{Plea bargaining}

On the day of the hearing, the defendant pleaded guilty to the reduced charges. The matter was subject to a plea bargain immediately prior to the hearing. The defendant would plead guilty on the basis that several charges were withdrawn. As a result of these plea bargain negotiations, the victim was not required to give evidence at the court hearing. Neither the family nor Noah had input into this decision. While Noah was relieved that he would not be required to give evidence, his parents were very unhappy that such negotiations took place without prior consultation. As far as they were concerned, their son deserved his day in court and felt that, with support, he could give evidence.

The sentencing hearing took less than one hour to conclude. Prior to sentencing, the magistrate addressed Noah directly. Asking him to stand, the magistrate affirmed to Noah that he was in "no way to blame for what had occurred and that the police were there to help him and he should not be afraid of police" (interview transcript, Noah). 


\section{Disabled in rural Victoria: Exploring the intersection of victimisation, disability and rurality on access to justice - Camilleri}

\section{Support to recover}

Despite the categorisation of the crime as a property crime, the impact and duration of the effects of the crime on Noah have been significant. For several months post the court hearing, Noah was still fearful and reluctant to leave the house. He lost confidence, consequently he did not drive and thus risked losing his part time job. Despite these consequences, Noah was unable to receive assistance from victims of crime services in order to assist with his recovery. Nor was he eligible to apply for any assistance from the Victims of Crime Assistance Tribunal (VoCAT), as these options are only available for victims of violent crimes. Interestingly, however, the magistrate on this occasion suggested that the family lodge an application with VoCAT and that he would support it.

\section{Discussion}

The challenges identified in this case study are not unique to nor are they solely attributable to residing in a rural location. However, it is clear that the experiences of accessing the justice system by people with cognitive impairment residing in rural areas presents additional layers of complexity.

The following discussion categorises and draws distinction between three layers: the first pertains to victims of crime generally; the second, to victims with cognitive impairment; and the third layer adds the dimension of rurality.

\section{Layer 1 - victims of crime}

Noah and his parents' interaction with police was not, for the most part, a positive experience. Assumptions made by the police, at the point of first report, about Noah's capacity as a witness continue to resonate with Noah, as does the frustration of not being kept informed during the investigation. Available literature about the experiences of victims of crime with the justice system suggest that victims' interactions with police and courts can be a source of secondary victimisation (Doak, 2015; VLRC, 2016; Wemmers, 2013). In addition to the outcome of matters at court, it is procedural justice or the perceived fairness of procedures, which will determine if victims felt that they were treated fairly by the justice system (Doak, 2015; Wemmers, 2013). Being treated with dignity and respect will also contribute to victims' sense of procedural justice (Wemmers 2013), as will the provision of information "before, during and post court hearing" (Victims Support Agency, 2013, p. 25). Elliot, Thomas and Ogloff (2014) argue that a positive interaction between police and the victim, including police validation of the victim's experience, can have a positive impact on victims' recovery from victimisation.

Research into the experiences of victims of crime and their interaction with the justice system have also highlighted how victims have felt alienated from proceedings (Doak, 2015; VLRC, 2016). Increasingly, however, victims have been an important stakeholder in the criminal justice process (VLRC, 2016). According to the literature, the challenges experienced by Noah and his parents, about being excluded from decisions regarding plea or charge negotiations resulting in the down grading of charges, or in exchange for a guilty plea are similar to the experiences of other victims of crime (Flynn, 2011; VLRC, 2016).

With respect to consultations with victims about plea negotiations, the Victorian Law Reform Commission (VLRC, 2016) in its final report, which considered the role of 
victims in the criminal trial process, made a specific recommendation. In summary, recommendation 24 (p. 142) suggests that the Victims Charter Act 2006 be amended to reflect that while the views of victims should not be determinative, their views should be sought and information provided by prosecuting agencies in regards to modifying charges and prosecution discontinuation (VLRC, 2016). The recommendation was included in the Victims and Other Legislation Amendment Bill, receiving royal assent on 11 September 2018.

The effects of crime can be long lasting (Wemmers, 2013). In Victoria, victims of violent crime may be eligible for services to assist recovery from the effects of victimisation and/or financial assistance that will assist them to recover from the effects of crime (Victims' Charter Act 2006 (Vic)). However, limited services are available for people with disability (such as Noah) who may be adversely affected by property crime, unless such victims pay for privately funded assistance.

\section{Layer 2 - victims of crime with cognitive impairment}

In addition to the challenges described above, victims with cognitive impairment are also subject to assumption that the people with cognitive impairment lack capacity and credibility (AHRC, 2014; Camilleri, 2008, 2010; French, 2007; VEOHRC, 2014).

Consultations with police conducted by the Victorian Equal Opportunity and Human Rights Commission (VEOHRC, 2014) highlight that police acknowledge the challenges they face when interacting with people with cognitive and other types of impairments.

Police and prosecutors play a critical gatekeeping role in accepting and progressing reports made to them by victims of crime. In reports of sexual assault (Camilleri, 2008, 2010; Murray \& Heenan, 2012; Lievore, 2004) and other crimes to police (AHRC, 2014; Parliament of Victoria, 2016; VEHRC, 2014), assessments made with respect to capacity and credibility are typically made at first report.

An assessment of capacity is also made at the interview stage (Lievore, 2004). The Evidence Act 2008 (Vic) (Part 2.1 Witnesses, s.12 \& s.13) state that "every person is competent to give evidence" (s.12). In summary, a lack of competency is defined as the inability of the witness to understand the questions and to provide an intelligible response. Crucially the Act also states "where the incapacity cannot be overcome" (s.13). Currently, support when making a statement to police is not available to victims with cognitive impairment, unless they are children or are victims of sexual assault. Similarly, services such as that offered by the Independent Third Person Program, managed by the Office of the Public Advocate, are not available to victims, only to people with a cognitive impairment being interviewed in relation to a criminal offence (Office of the Public Advocate, n.d.).

Intermediary or communication assistant programs have or are in the process of being introduced in other jurisdictions in Australia, including in New South Wales, South Australia, Western Australia and Tasmania. Such programs are modelled, in part, on the intermediary program in England, Wales and Northern Ireland. Victoria is currently implementing a pilot intermediary program, which commenced in July 2018 (State Government, 2017). Briefly, the role of the Intermediary includes assessing the communication needs of victims; providing advice to police, court, prosecution and defence about how questions should be framed; and advising of other accommodations to assist the person to provide their best evidence (Plotnikoff \& Woolfson, 2015). 


\section{Disabled in rural Victoria: Exploring the intersection of victimisation, disability and rurality on access to justice - Camilleri}

The use of intermediaries has been supported with recent legislative changes to the Criminal Procedure Act 2009 (Vic) Part 8.2A (Aust.). It is unclear whether in the medium to long term this initiative will be available for all witnesses (residing in urban, rural and regional areas) with cognitive impairment who require the assistance of an intermediary. At this stage, the pilot only includes matters with respect to sexual assault and homicide where the victims are either children or adults with intellectual disability. Intermediaries are typically called to assist after a report is made and accepted. Hence, irrespective of the extent of the proposed intermediary program, discretionary decisions made by police not to take the report in the first instance may still potentially create barriers for people with cognitive impairment to report crimes.

The decision to downgrade the charges appeared to be based, at least in part, on the quality of the interviews. Arguably, had a support person been provided - or indeed greater police awareness about how to frame questions to meet the comprehension needs of the victim - perhaps the matter may not have been downgraded as police may have had more confidence in Noah's capacity to provide evidence in court.

\section{Layer 3 - victims of crime with cognitive impairment residing in rural areas}

The challenges that distinguish and compound Noah's experiences and indeed the experiences of other victims with cognitive impairment, are linked to rurality. Indeed, Noah's experience, in particular traveling long distances to access courts and police station, is usual for people who reside in rural locations. In Noah's case, the local police station was relatively close - less than 15 kilometres (9.3 miles) to and from home - but he was required to travel to the larger regional town, approximately a 200 kilometre (124 mile) return journey, for the interview to be conducted at the larger police station. Noah and his family made this journey to attend the police station and court on at least three occasions. The challenge of distance was highlighted by the Law Council of Australia (2018) and others, suggesting that traveling such distances can be an impediment to accessing the justice system, for defendants (Coverdale, 2011), victims' and defendants' (George \& Harris, 2014; Pruitt, 2008; VEOHRC, 2014).

Reduced capacity and resources is characteristic of other services, such as mental health services, seeking to provide services in rural areas (King, 2018). Limited resources and reduced capacity in rural police stations means that victims with cognitive impairments will continue to be required to attend the larger police station. However, as Noah's case has identified, the expertise in interviewing a person with a cognitive impairment at the regional police station may have also been limited. Noah and his family would have been well placed to provide advice to the police on his communication needs.

The perception or assessment of reliability and credibility of the prosecution witness are factors that can inform police or prosecutor decision to enter plea and or charge negotiations (VLRC, 2016, p. 255). In Noah's case, the dissatisfaction with the interview, expressed by police, appears to have been an important factor in the decision to negotiate charges and plea. It is interesting to contemplate whether providing the support Noah required during the interview, and training or support for police officers to conduct interviews with people with cognitive impairment, may have altered their decision to pursue a negotiated outcome. 
Reflecting on Noah's case from beginning to finalisation at court and his continued recovery from his victimisation experience, it is clear that in Noah's case this is not a course of action Noah could have taken on his own. As the literature makes salient (Camilleri, 2008, 2010; Flynn, 2013; VEOHRC, 2014) the role of advocacy, in this case by Noah's parents, plays an important role in delivering equitable access to justice.

Noah's experience highlights that further reforms are required in order to increase access to systems and procedures used in the administration of the justice system. These include, but are not limited to:

- adequate resources and training of police officers in regional and rural areas - in particular, training is required to ensure that interviews are conducted in a way that enhances, rather than diminishes the opportunity for the victim to tell their story

- support during an interview of a vulnerable witness

- training of police prosecutors to raise awareness of the range of support measures available for victims deemed to be 'vulnerable witnesses', and indeed in determining if the victim meets the current criteria of a 'vulnerable' witness

- cultural change (police and police prosecutors) in regards to recognising that people with cognitive impairments are not homogenous and, as such, decisions in regard to a victim's capacity and credibility based solely on disability should be avoided

- broader legislative definitions of 'who is a victim of crime'

\section{Conclusion}

The challenges which impede access to justice systems, procedures and processes for victims with disability are not unique to this case. Indeed, the case study supported by the literature suggests that the experiences described are similar to that of other victims of crime. However, the case study does highlight the intersectional challenges faced by victims with cognitive impairment, and the further challenges posed by residing in rural areas. Such challenges are likely to work in combination to: (a) maintain the reduced status on the victim hierarchy; (b) impede victims' from accessing equitable justice; and (c) lead to compromised outcomes. The consequence of inaccessible justice, in particular for people with cognitive impairment and complex communication needs, is that such victims are rendered easy targets.

Research focusing on the intersectional dimensions of victims with disability, in particular those who reside in rural areas, is sparse to say the least. I take this opportunity to remind researchers of the vital role they can play - and indeed have previously played - in shedding light into the dark corners of the experiences of such victims, and on the systems of justice which remain unchallenged. There are multiple perspectives from which research about victims with disability within a rural context can be approached. I encourage scholars to think creatively, partner with disability groups and indeed people with disabilities to make salient the access to justice needs of people with disability in rural areas.

\section{Endnotes}

${ }^{1}$ This article stems from a larger project funded by the Victoria Legal Services Board. 


\section{Disabled in rural Victoria: Exploring the intersection of victimisation, disability and rurality on access to justice - Camilleri}

${ }^{2}$ See Law Council of Australia (2018); Parliament of Victoria (2016); Department of Justice (2016); Senate Community Affairs References Committee (2015); Victorian Ombudsman (2015); Royal Commission into Family Violence (2016); Australian Law Reform Committee (2014); VEOHRC (2014); AHRC (2014); PWDA (2014); Civil Society (2012) and Victorian Law Reform Commission (2004, 2014).

${ }^{3}$ According to the Crimes Act 1958 (Vic) s.52A, cognitive impairment includes impairment because of intellectual disability, dementia, neurological disorder or brain injury.

4 'Complex communication needs' is a broad term that refers to difficulties communicating using speech and writing, or difficulties understanding how others communicate. Complex communication needs can be associated with developmental disability, such as intellectual disability or autism, or acquired disability like brain injury or stroke (FCDC, 2015, p. 79).

\section{References}

ABS (Australian Bureau of Statistics). (2015). Disability, ageing and carers, Australia: Summary of findings 2015. Cat. 4430.0. Retrieved from http://www.abs.gov.au/ausstats/abs@.nsf/mf/4430.0

ABS (Australian Bureau of Statistics). (2016). Personal safety survey. Cat 4906.0. Retrieved from https://www.abs.gov.au/ausstats/abs@.nsf/mf/4906.0

AHRC (Australian Human Rights Commission). (2014). Equal before the law: Towards disability justice strategies. Retrieved from https://www.humanrights.gov.au/equallaw-towards-disability-justice-strategies

ALRC (Australian Law Reform Committee). (2014, August). Final report: Equality, Capacity and Disability in Commonwealth Laws, ALRC Report 124. Retrieved from https://www.alrc.gov.au/publication/equality-capacity-and-disability-incommonwealth-laws-alrc-report-124/

Anthias, F. (2013). Intersectional what? Social divisions, intersectionality and levels of analysis. Ethnicities, 13(1), 3-19. https://doi.org/10.1177/1468796812463547

Baldry, E., Dowse, L. and Clarence, M. (2012). People with intellectual and other cognitive disabilities in the criminal justice system. Sydney, NSW: University of New South Wales.

Camilleri, M. (2008). Enabling justice. Paper presented at the National Victims of Crime Conference 'New Ways Forward - Pathways to Change', 23-24 September 2008, Adelaide. Retrieved from http://library.aic.gov.au/cgi-bin/koha/opacsearch.pl?idx $=\& q=$ Camilleri

Camilleri, M. and Pedersen. C. (2019). Hear Us: The experiences of persons with complex communication needs in accessing justice. Ballarat, Vic: Federation University Australia. Retrieved from https://www.lsbc.vic.gov.au/documents/ReportFederation_University_Australia_Marg_Camilleri_Complex_Communication_Needs2019.pdf 
Camilleri. M. (2010). [Dis] Abled justice: Why reports of sexual assault made by adults with cognitive impairment fail to proceed through the justice system (doctoral thesis). University of Ballarat, Ballarat, Vic.

Campbell, F.K. (2001). Inciting legal fictions: 'Disability's' date with ontology and the ableist body of law. Griffith University Review, 10(1), 42-62. https://researchrepository.griffith.edu.au/handle/10072/3714

Civil Society. (2012). Disability rights now: Civil Society report to the United Nations Committee on the Rights of Persons with Disabilities. Retrieved from https://www.advokit.org.au/wp content/uploads/2013/06/CRPD_Civil_Society_Report_PDF.pdf

CRPD (Convention on the Rights of Persons with a Disability) (2010). Preamble. United Nations. Retrieved from https://www.un.org/development/desa/disabilities/convention-on-the-rights-ofpersons-with-disabilities/convention-on-the-rights-of-persons-with-disabilities-2.html

Courmarelos, C., Macourt, D., People, J., McDonald, H.M., Wei, Z., Iriana, R. and Ramsey, S. (2012). Legal Australia-wide survey legal need in Victoria. Access to justice and legal needs. Vol. 14. New South Wales Law and Justice Foundation.

Coverdale. R. (2011). Postcode justice: Rural and regional disadvantage in the administration of the law in Victoria. Deakin Law Review, 16(1), 155-187.

https://doi.org/10.21153/dlr2011vol16nolart98

Crenshaw. K. (Jul., 1991). Mapping the margins: Intersectionality, identity politics, and violence against women of color. Stanford Law Review, 43(6), 1241-1299. https://doi.org/10.2307/1229039

Crimes Act 1958 (Vic). Retrieved from http://classic.austlii.edu.au/au/legis/vic/consol_act/ca195882/

Criminal Procedure Act 2009 (Vic). Retrieved from http://classic.austlii.edu.au/au/legis/vic/consol_act/cpa2009188/

DeKeseredy. W. (2019). Intimate violence against rural women: The current state of sociological knowledge. International Journal of Rural Criminology, 4(2), 1-21. https://doi.org/10.18061/1811/87904

Doak. J. (2015, 19 October). Submission to Victims of crime in the criminal trial process Victorian Law Reform Commission. Retrieved from https://www.lawreform.vic.gov.au/sites/default/files/Submission_CP_31_Professor_J ohnathon_Doak_20-10-15.pdf

DoJR (Department of Justice and Regulation). (2016). Access to Justice Review: Summary Report and Recommendations. Retrieved from https://s3.ap-southeast 2.amazonaws.com/hdp.au.prod.app.vicengage.files/9814/8601/7130/Access_to_Justic e_Review_-_Summary_and_recommendations.PDF 


\section{Disabled in rural Victoria: Exploring the intersection of victimisation, disability and rurality on access to justice - Camilleri}

Donnermeyer, J., Scott, J. and Barclay. E. (2013). How rural criminology informs critical thinking in criminology. International Journal of Crime Justice and Social Democracy, 2(3), 69-91. https://doi.org/10.5204/ijcjsd.v2i3.122

Edwards, C. (2013). Spacing access to justice: Geographical perspectives on disabled people's interaction with the criminal justice system as victims of crime. Area, 45(3), 307-313. https://doi.org/10.1111/area.12034

Edwards, C., Harold, G. and Kilcommins, S. (2012). Access to justice for people with disabilities as victims of crime in Ireland. University College, Cork: National Disability Authority.

Edwards, C., Harold, G. and Kilcommins, S. (2015). 'Show me a justice system that's open, transparent, accessible and inclusive': Barriers to access in the criminal justice system for people with disabilities as victims of crime. Irish Journal of Legal Studies, 5(1), 86-105. Retrieved from https://ulir.ul.ie/bitstream/handle/10344/4575/Kilcommins_2015_crime.pdf;sequence $=1$

Ellem, K. and Richards, K. (2018). Police contact with young people with cognitive disabilities: Perceptions of procedural (in)justice. Youth Justice, 18(3), 230-247. https://doi.org/10.1177/1473225418794357

Elliott. I., Thomas. S. and Ogloff. J. (2014). Procedural justice in victim-police interactions and victims' recovery from victimisation experiences. Policing and Society, 24(5), 588-601. https://doi.org/10.1080/10439463.2013.784309

Evidence Act 2008 (Vic). Retrieved from http://classic.austlii.edu.au/au/legis/vic/consol_act/ea200880/

FCDC (Family and Community Development Committee). (2016). Inquiry into abuse in disability services: Final report. Melbourne, Vic: Parliament of Victoria. Retrieved from https://www.parliament.vic.gov.au/file_uploads/FCDC__Inquiry_into_abuse_in_disability_services_HtW37zgf.pdf

Flynn, A. (2011). Bargaining with justice: Victims, plea bargaining and the Victims' Charter Act 2006 (Vic). Monash University Law Review, 37(3), 73-96. Retrieved from http://classic.austlii.edu.au/au/journals/MonashULawRw/2011/29.html

Flynn, E. (2013). Making human rights meaningful for people with disabilities: Advocacy, access to justice and equality before the law. The International Journal of Human Rights, 17(4), 491-510. https://doi.org/10.1080/13642987.2013.782858

Fogden, B.C., Thomas, S.D.M., Daffern, M. and Ogloff, J.R.P. (2016). Crime and victimisation in people with intellectual disability: a case linkage study. $B M C$ Psychiatry 16 (article 170), 1-9. https://doi.org/10.1186/s12888-016-0869-7

French, P. (2007). Disabled Justice: The barriers to justice for persons with disability in Queensland. Brisbane, Qld: Queensland Advocacy Incorporated.

French. R. (2011). Law and Justice outside the CBD. Deakin Law Review, 16(1), 1-12. https://doi.org/10.21153/dlr2011vol16nolart91 
Garland Thomson, R. (1997). Extraordinary bodies: Figuring physical disabilities in American culture and literature. New York, NY: Columbia University Press.

George, A. and Harris, B. (2014). Landscapes of violence: Women surviving family violence in rural and regional Victoria. Geelong, Vic: Centre for Rural and Regional Law and Justice. Deakin University.

Goodfellow, J. and Camilleri, M. (2003). Beyond belief, beyond justice: The difficulties for victims/survivors with disabilities when reporting sexual assault and seeking justice. Melbourne, Vic: Disability Discrimination Legal Service.

Goodley, D. (2001). 'Learning difficulties', the social model of disability and impairment: Challenging epistemologies. Disability and Society 16(2), 207-231. https://doi.org/10.1080/09687590120035816

Hall-Sanchez, A. (2016). Intimate violence against rural women: The current and future state of feminist empirical and theoretical contributions. Sociology Compass, 10(4), 272283. https://doi.org/10.1111/soc4.12358

Hawkins, J.M. (2018). Thematic analysis. In M. Allen (Ed.) The SAGE encyclopaedia of communication research methods. Thousand Oaks, CA: SAGE Publications.

Jankowitz, S. (2018). The 'hierarchy of victims' in Northern Ireland: A framework for critical analysis. International Journal of Transitional Justice, 12(2), 216-236. https://doi.org/10.1093/ijtj/ijy003

Jordan, J. (2004). The word of a woman? Police, rape and belief. Houndsmills, UK: Palgrave Macmillan. https://doi.org/10.1057/9780230511057

Kayess, R. and French, P. (2008). Out of the darkness into the light? Introducing the Convention on the Rights of Persons with Disabilities. Human Rights Law Review, 8(1), 1-34. https://doi.org/10.1093/hrlr/ngm044

Kilcommins, S. and Donnelly, M. (2014). Victims of crime with disabilities in Ireland: Hidden casualties in the 'vision of victim as everyman'. International Review of Victimology, 20(3), 305-325. https://doi.org/10.1177/0269758014537149

King, E. (2018). Accessibility and quality of mental health services in rural and remote Australia. Victorian Council of Social Services submission to the Senate Standing Committee on Community Affairs. Retrieved from https://vcoss.org.au/policy/accessibility-and-quality-of-mental-health-services-inrural-and-remote-australia/

Larson, D.A. (2014). Access to justice for persons with disabilities: An emerging strategy. Laws, 3, 220-238. https://doi.org/10.3390/laws3020220

Law Council of Australia. (2018). Access to justice. The Justice Project final report - Part 1. Retrieved from https://www.lawcouncil.asn.au/justice-project/final-report 


\section{Disabled in rural Victoria: Exploring the intersection of victimisation, disability and rurality on access to justice - Camilleri}

Lievore. D. (2004). Prosecutorial decisions in adult sexual assault cases: An Australian study. Canberra: Australian Institute of Criminology. Retrieved from https://aic.gov.au/publications/archive/prosecutorial-decisions-in-adult-sexual-assaultcases

Loja, E., Costa, M.E., Hughes, B. and Menezes, I. (2013). Disability, embodiment and ableism: Stories of resistance. Disability and Society, 28(2), 190-203. https://doi.org/10.1080/09687599.2012.705057

Magistrates' Court Act 1989 (Vic). Retrieved from http://www6.austlii.edu.au/cgibin/viewdoc/au/legis/vic/consol_act/mca1989214/s4k.html

Martin, W. (2014, 26 February). Access to justice. Inaugural lecture for the University of Notre Dame Eminent Speakers' Series, 1-21. Retrieved from https://www.supremecourt.wa.gov.au/_files/Access\%20to\%20Justice\%20by\%20Mart in $\% 20 \mathrm{CJ} \% 2026 \% 20 \mathrm{Feb} \% 202014$.pdf

McCausland, R. and Baldry, E. (2017). 'I feel like I failed him by ringing the police': Criminalising disability in Australia. Punishment and Society, 19(3), 290-309. https://doi.org/10.1177/1462474517696126

McEvoy, K. and McConnachie, K. (2012). Victimology in transitional justice: Victimhood, innocence and hierarchy. European Journal of Criminology, 9(5), 527-538. https://doi.org/10.1177/1477370812454204

McGuire, M. (2012). Breaking the cycle: Using advocacy-based referrals to assist people with disabilities in the criminal justice system. Carlton, Vic: Office of the Public Advocate. Retrieved from https://www.publicadvocate.vic.gov.au/ourservices/publications-forms/research-reports/justice-system/65-breaking-the-cyclesummary-report/file

McQuoid-Mason, D. (2013). Access to justice in South Africa: Are there enough lawyers? Oñati Socio-legal Series [online], 3(3), 561-579. Retrieved from http://ssrn.com/abstract=2272640

McSherry. B., Baldry. E., Arstein-Kerslake. A., Gooding. P, McCausland. R. and Arabena. K. (2017). Unfitness to plead and indefinite detention of persons with cognitive disabilities. Melbourne, Vic: Melbourne Social Equity Institute, University of Melbourne.

Meekosha. H. and Shuttleworth. R. (2009). What's so 'critical' about critical disability studies? Australian Journal of Human Rights, 15(1), 47-75. https://doi.org/10.1080/1323238X.2009.11910861

Murray, S. and Heenan, M. (2012). Reported rapes in Victoria: Police responses to victims with a psychiatric disability or mental health issue, Current Issues in Criminal Justice, 23(3), 253-268. https://doi.org/10.1080/10345329.2012.12035929

Nancarrow, H. (2006). In search of justice for domestic and family violence: Indigenous and non-Indigenous Australian women's perspectives. Theoretical Criminology, 10(1), 87-106. https://doi.org/10.1177/1362480606059986 
Office of the Public Advocate. (n.d.). About us. Retrieved from https://www.publicadvocate.vic.gov.au/about-us/

Oliver, M. (1990). The politics of disablement. Basingstoke, UK: McMillan. https://doi.org/10.1007/978-1-349-20895-1

Olsen. A and Lovett, R. (2016). Existing knowledge, practice and responses to violence against women in Australian Indigenous communities: State of knowledge paper. Australia's National Research Organisation for Women's Safety Limited (ANROWS).

Ortoleva, S. (2011). Inaccessible justice: Human rights, persons with disabilities and the legal system. ILSA Journal of International and Comparative Law, 17(297), 281-320.

Parliament of Victoria (2016). Family and Community Development Committee Inquiry into abuse in disability services Final Report. Victorian State Government https://www.parliament.vic.gov.au/file_uploads/FCDC_Inquiry_into_abuse_in_disa bility_services_HtW37zgf.pdf

People with Disability Australia. (2014). Submission to the Senate inquiry into the prevalence of different types of speech, language and communication disorders and speech pathology services in Australia. https://www.aph.gov.au/DocumentStore.ashx?id=23073658-8672-4905-978c8e6fla4a0130\&subId=251545

Plotnikoff, J. and Woolfson, R. (2015). Intermediaries in the criminal justice system. Bristol, UK: Policy Press. https://doi.org/10.2307/j.ctt1t89326

Pruitt, L.R. (2008). Place matters: Domestic violence and rural difference. Wisconsin Journal of Law, Gender and Society, 23(2), 347-416.

Pruitt, L.R. and Showman, B.E. (2014). Law stretched thin: Access to justice in rural America. South Dakota Law Review, 59(3), 466-528.

Pruitt, L.R., Kool, A., Sudeall, L., Statz M., Conway, D. and Haksgaard, H. (2018). Legal deserts: A multi-state perspective on rural access to justice. Harvard Law and Policy Review, 15. Georgia State University College of Law, Legal Studies Research Paper No. 2019-01. Retrieved from https://ssrn.com/abstract=3198411

Rapley, M. (2004). The social construction of intellectual disability. Cambridge, UK: Cambridge University Press. https://doi.org/10.1017/CBO9780511489884

Rennison, C.M., DeKeseredy, W.S. and Dragiewicz, M. (2013). Intimate relationship status variations in violence against women: Urban, suburban, and rural differences. Violence Against Women, 19(11), 1312-1330. https://doi.org/10.1177/1077801213514487

Rhode, D. and Cummings, S.L. (2017). Access to justice: Looking back, thinking ahead. Georgetown Journal of Legal Ethics, 30, 485-500. Retrieved from https://law.stanford.edu/publications/access-to-justice-looking-back-thinking-ahead/ 


\section{Disabled in rural Victoria: Exploring the intersection of victimisation, disability and rurality on access to justice - Camilleri}

Royal Commission into Family Violence. (2016). Summary and recommendations report. Melbourne, Vic: Victorian Government. Retrieved from http://files.rcfv.com.au/Reports/Final/RCFV-All-Volumes.pdf

Schetzer, L. and Henderson, J. (2003). Public consultations: A project to identify legal needs, pathways and barriers for disadvantaged people in NSW. Access to justice and legal needs Vol. 1. Sydney, NSW: Law and Justice Foundation of NSW. Retrieved from http://www.lawfoundation.net.au/report/consultations/7168739E45C7CA57CA25706 0007D4EDC.html

Senate Community Affairs References Committee. (2015) Violence, abuse and neglect against people with disability in institutional and residential settings, including the gender and age related dimensions, and the particular situation of Aboriginal and Torres Strait Islander people with disability, and culturally and linguistically diverse people with disability. Canberra, ACT: Commonwealth of Australia.

Shakespeare, T. (2013). The social model of disability. In L.J. Davis (Ed.), The disability studies reader (pp. 214-221). New York, NY: Routledge.

Shepherd, S., Ogloff, J., Paradies, Y. and Pfeifer, J. (2017). Aboriginal prisoners with cognitive impairment: Is this the highest risk group?. Trends and Issues in Crime and Criminal Justice, no. 536. Canberra, ACT: Australian Institute of Criminology. Retrieved from https://aic.gov.au/publications/tandi/tandi536

Soldatic, K. and Johnson. K. (2017a). Disability and rurality: Identity, gender and belonging. In K. Soldatic and K. Johnson. (Eds.). Disability and rurality: Identity, gender and belonging (pp. 1-2). Oxford, UK: Routledge. https://doi.org/10.4324/97813155773401

Soldatic, K. and Johnson. K. (2017b). Conclusion. In K. Soldatic and K. Johnson. (Eds.). Disability and rurality: Identity, gender and belonging (pp. 244-249). Oxford, UK: Routledge. https://doi.org/10.4324/9781315577340-18

Spaan, N.A. and Kaal, H.L. (2019). Victims with mild intellectual disabilities in the criminal justice system. Journal of Social Work, 19(1), 60-82. https://doi.org/10.1177/1468017318757331

Thomas, C. (2004). How is disability understood? An examination of sociological approaches. Disability and Society, 19(6), 569-583. https://doi.org/10.1080/0968759042000252506

United Nations. (2018, January). The United Nations and disability: 70 years of the work towards a more inclusive world. New York, NY: Division for Social Policy and Development, United Nations Department of Economic and Social Affairs.

UNDP (United Nations Development Programme). (2005). Programming for Justice: Access for All. Cited in A.W. Bedner and J.A. Vel. (2010). An analytical framework for empirical research on Access to Justice. Law, Social Justice and Global Development Journal, 15(1), 1-29. 
VEOHRC (Victorian Equal Opportunity and Human Rights Commission). (2014, July). Beyond doubt: The experiences of people with disabilities reporting crime. Victorian Equal Opportunity and Human Rights Commission. Retrieved from https://www.humanrightscommission.vic.gov.au/our-resources-andpublications/reports/item/894-beyond-doubt-the-experiences-of-people-withdisabilities-reporting-crime

VicHealth. (2012). Disability and health inequalities in Australia Research summary. Melbourne, Vic: Victorian Health Promotion Foundation. Retrieved from https://www.vichealth.vic.gov.au/media-and-resources/publications/disability-andhealth-inequalities-in-australia

Victims Support Agency. (2013). Information and support needs of victims and witnesses in the Magistrates' Court of Victoria. Melbourne, Vic: Department of Justice. Retrieved from https://www.victimsofcrime.vic.gov.au/information-and-support-needs-ofvictims-and-witnesses-in-the-magistrates-court

Victims' Charter Act 2006 (Vic) Retrieved from http://www8.austlii.edu.au/cgibin/viewdb/au/legis/vic/consol_act/vca2006175/

Victorian Law Reform Commission. (2004). Sexual offences: final report. Melbourne, Vic: Victorian Law Reform Commission. Retrieved from https://www.lawreform.vic.gov.au/projects/sexual-offences/sexual-offences-finalreport

Victorian Law Reform Commission. (2016). The role of victims of crime in the criminal trial process. Melbourne, Vic: Victorian Law Reform Commission. Retrieved from http://lawreform.vic.gov.au/projects/victims-crime-criminal-trial-process/victimscrime-criminal-trial-process-pdf

Victorian Ombudsman. (2015). Reporting and investigation of allegations of abuse in the disability sector, Phase 1 - the effectiveness of statutory oversight. Retrieved from https://www.ombudsman.vic.gov.au/getattachment/c6499f78-0eec-4e4a-8e94e4cd716a64f8

Victorian State Government. (2017, 7 May). Supporting victims of crime in the justice system. Media release. Retrieved from https://www.premier.vic.gov.au/supportingvictims-of-crime-in-the-justice-system/

Wemmers, J. (2013). Victims' experiences in the criminal justice system and their recovery from crime. International Review of Victimology, 19(3), 221-233. https://doi.org/10.1177/0269758013492755

World Health Organization and World Bank. (2011). World report on disability. Geneva: World Health Organization. Retrieved from https://www.who.int/disabilities/world_report/2011/report/en/ 